\title{
Fermentative degradation of glyoxylate by a new strictly anaerobic bacterium
}

\author{
Michael Friedrich and Bernhard Schink \\ Lehrstuhl Mikrobiologie I, Eberhard-Karls-Universität, Auf der Morgenstelle 28, W-7400 Tübingen, Federal Republic of Germany
}

Received March 15, 1991/Accepted June 16, 1991

\begin{abstract}
A new strictly anaerobic, gram-negative, nonsporeforming bacterium, Strain PerGlx1, was enriched and isolated from marine sediment samples with glyoxylate as sole carbon and energy source. The guanineplus-cytosine content of the DNA was $44.1 \pm 0.2 \mathrm{~mol} \%$. Glyoxylate was utilized as the only substrate and was stoichionetrically degraded to carbon dioxide, hydrogen, and glycolate. An acetyl-CoA and ADP-dependent glyoxylate converting enzyme activity, malic enzyme, and pyruvate synthase were found at activities sufficient for growth ( $\geq 0.25 \mathrm{U} \times \mathrm{mg}$ protein $\left.^{-1}\right)$. These findings allow to design a new degradation pathway for glyoxylate: glyoxylate is condensed with acetyl-CoA to form malylCoA; the free energy of the thioester linkage in malyl$\mathrm{CoA}$ is conserved by substrate level phosphorylation. Part of the electrons released during glyoxylate oxidation to $\mathrm{CO}_{2}$ reduce a small fraction of glyoxylate to glycolate.
\end{abstract}

Key words: Glyoxylate - Anaerobic degradation Malic enzyme - Substrate level phosphorylation

Glyoxylic acid is an important monocarboxylic acid found in unripe fruits as well as in green leaves of many plants, e.g. apple, plum, rhubarb, currant, gooseberry, and wine (Brunner and Chuard 1886) and in young sugar beets (von Lippmann 1894). Furthermore, glyoxylate is excreted by certain algal species (Stewart and Codd 1981). As intermediate, glyoxylate is involved in various metabolic pathways: e.g. in purine degradation by Pseudomonas aeruginosa and $P$. acidovorans, in the serine-isocitrate-lyase pathway of many methylotrophic microorganisms, and the glyoxylate cycle in acrobic and nitratereducing bacteria (Gottschalk 1986).

Metabolism of glyoxylate under aerobic conditions is well documented, and several different pathways are known: the glycerate pathway (Hansen and Hayashi

Offprint requests to: $\mathrm{M}$. Fricdrich
1962), a dicarboxylic acid pathway with malate as key intermediate (Kornberg and Sadler 1960), and the $\beta$ hydroxyaspartate pathway (Kornberg and Morris 1965). Glyoxylate degradation under strictly anaerobic conditions has not yet been studied. This paper reports for the first time on fermentative degradation of glyoxylate by a new strictly anaerobic bacterium to carbon diexide, hydrogen, and glycolate. All enzymes involved in glyoxylate degradation were measured, and a catabolic pathway is proposed.

\section{Materials and methods}

\section{Source of organisms}

Strain PerGlx1 was isolated from an enrichment culture inoculated with anoxic black marine sediment of Rio della Pergola, a canal located in the city of Venice, Italy.

Methanospirillam hungatei strain SK was obtained from Prof. Dr. F. Widdel, München, FRG.

\section{Media and growth conditions}

All procedures for cultivation and isolation were as previously described (Widdel and Pfennig 1981; Schink and Pfennig 1982; Schink 1984). The mineral medium for cnrichment, isolation and cultivation contained $30 \mathrm{mM}$ sodium bicarbonate as buffer, $1 \mathrm{mM}$ sodium sulfide as reducing agent, $20 \mathrm{nM}$ selenite and tungstate, the trace element solution SL 10 (Widdcl et al. 1983), and 7-vitamin solution (Widdel and Pfonnig 1984). The $\mathrm{pH}$ was adjusted to $7.2-7.4$. Freshwater medium contained $0.5 \mathrm{~g} \mathrm{NaCl}$ and $0.4 \mathrm{~g} \mathrm{MgCl}_{2} \times 6 \mathrm{H}_{2} \mathrm{O}$, stitwater medium $20 \mathrm{~g} \mathrm{NaCl}$ and $3 \mathrm{~g} \mathrm{MgCl}_{2} \times 6 \mathrm{H}_{2} \mathrm{O}$, respectively, per liter. Growth experiments were carried out at $28^{\circ} \mathrm{C}$. Growth was determined by turbidity measurement at $500 \mathrm{~mm}$ wavelength either in a Spectronic 20 Spectrophotometer (Bausch \& Lomb, Rochester. NY, USA) or in a Hitachi 100-40 spectrophotometer (Hitachi, Tokyo, Japan).

Methanospiriltum hungatei strain $\mathrm{SK}$ was grown in freshwater medium containing $5 \mathrm{mM}$ sodium acetate in $120-\mathrm{ml}$ serum flasks filled with $50 \mathrm{ml}$ medium under an atmosphere of $80 \% \mathrm{H}_{2} / 20 \%$ $\mathrm{CO}_{2}$. 


\section{Isolation and characterization}

For isolation of purc cultures, the agar shake dilution method was applied (Pfennig 1978). Culture purity was cheeked raicroscopically after growth in defined medium and after growth tests in complex media containing yeast extract, fumarate, pyruvate, and glucose. Gram staining was carried out according to Bartholomew (1962) with Acetobacterium woodil and Escherichia coll as controls. In addition. the Gram type was checked by the $\mathrm{KOH}$ method (Gregersen 1978).

Detection of cytochromes was carried out as described previously (Dörner and Schink 1990). The guanine-plus-cytosine content was determined by the thermal denaturation method (DeLey 1970, Marmur 1961).

\section{Chemical analyses}

Glyoxylatc was determined colorimetrically by a colour reaction with dinitrophenylhydrazine (Yamada and Jakoby 1958). Hydrogen was assayed by gas chromatography as described earlier (Matthies et al. 1989). Glycolate was analyzed with a Beckman System Gold high-pressure liquid chromaiograph (München, FRG) equipped with a LiChrospher 100 RP-18 encapped column (4 by $250 \mathrm{~mm}$; Merck, Darmstadt, FRG) connected to an Ultrasphere-ODS column ( 4.6 by 150 mm; Beckman Instruments, Mervue, Galway, Ireland), with $4.5 \mathrm{mM}$ potassium phosphate buffer ( $\mathrm{pH} 2.5$ ). Samples of culture supernatant $(20 \mu 1)$ were acidified with phosphoric acid (final concentration $100 \mathrm{mM}$ ), injected with a Spark Promise II autosampler (Spark Holland BV, Emmen, The Nethetlands), and eluted at a flow rate of $1 \mathrm{ml} / \mathrm{min}$. Poak clution was followed with a Beckman 167 detector at $205 \mathrm{~nm}$ wavelength. Chromatograms werc analyzed by a computer program and the amount of glycolate in samples was measured by comparison with extcrnal standards of known concentration.

Formation of nitrite from nitrate was assayed by azo dye formation with sulfanilic acid and $x$-naphthylamine (Procházková 1959). Sulfide formation from sulfur or sulfate was analyzed qualitatively by a rapid detection test (Cord-Ruwisch 1985). Protein was determined after Bradford (1976) with bovine serum albumine as standard.

\section{Enzyme measurements}

Cells were grown in $100 \mathrm{ml}$ freshwater mineral medium with $\mathrm{Na}$ glyoxylate added successively in $10 \mathrm{mM}$ steps up to a final concentration of $50 \mathrm{mM}$ glyoxylate.

Cell suspensions were harvested in the late logarithmic growth phase by centrifugation at $3,300 \times g$ for $20 \mathrm{~min}$, washed, and resuspended in $125 \mathrm{mM}$ potassium phosphatic buffer $(\mathrm{pH} 7.0)$ prereduced with $2.5 \mathrm{mM}$ dithioerythritol. Crude extracts were prepared anoxically by French Press treatment at $140 \mathrm{MPa}$. After removal of cell debris at $5,000 \times g$ for $20 \mathrm{~min}$, the crude extract was stored on ice.

Cuvettes $(1.5 \mathrm{ml} ; \mathrm{d}=1 \mathrm{~cm})$ sealed with rubber stoppers and gassed with $\mathrm{N}_{2}$ were employed to determine enzyme activities spectrophotometrically in a Hitachi $100-40$ spectrophotonteter (Hitachi, Tokyo, Japan) at $25^{\circ} \mathrm{C}$. All buffers and stock solutions were anoxic. Assay mixtures contained cell extract with $20-120 \mu \mathrm{g}$ protein. Dependence of reaction rates on protein contents was checked in all cases. Enzyme nomenclature and EC-numbers are based on the International Union of Biochemistry (1984).

Glyoxylate reductase $(\mathrm{EC}$ 1.1.1.26) was measured following NADH oxidation at $365 \mathrm{~nm}$ wavelength. The assay modified after 7cltich (1953) and contained potassium phosphate buffer, $\mathrm{pH} 7.0,120 \mathrm{mM}$ : NADH, $0.3 \mathrm{mM}$. The reaction was started with Na-glyoxylate, $2.5 \mathrm{mM}$

Malyl-CoA lyase (EC 4.1.3.24)/malate-CoA ligase (EC 6.2.1.9) activities were deternined as a reaction chain: (i) by coupling the conversion of acetyl-CoA + glyoxylate to $\mathrm{L}-$ malate via malyl-CoA with malyl-CoA lyase, malate:CoA ligese and malic enzyme reactions. The cell extract contained all three enzyme activities. The activity of both, malyl-CoA lyase and malate:CoA ligase could be followed as formation of $\mathrm{NADPH}$ from $\mathrm{NADP}^{+}$at $365 \mathrm{~nm}$ wavelength (malic enzyme reaction). The assay mixture contained: potassium phosphate buffer, $\mathrm{pH} 7.5,100 \mathrm{mM}$; DTE, $2.0 \mathrm{mM} ; \mathrm{MgCl}_{2}, 10 \mathrm{mM} ; \mathrm{NADP}^{+}, 1 \mathrm{mM} ; \mathrm{Na}_{2}$ ATP, $5 \mathrm{mM}$ and Na-glyoxylate, $15 \mathrm{mM}$. Li ${ }_{3}$-acetyl-CoA, $0.5 \mathrm{mM}$, was added to start the reaction.

(ii) by coupling the conversion of L-malate io acetyl-CoA and glyoxylate via malyl-CoA with malate:CoA ligase and malyl-CoA lyase (Tuboi and Kikuchi 1965), and monitoring phenylhydrazone formation at $324 \mathrm{~nm}$ wavelength. The modified assay mixture contained: Tris/glycine, pH 7.4, $140 \mathrm{mM}$; DTE, $2 \mathrm{mM} ; \mathrm{MgCl}_{2}$, $10 \mathrm{mM} ; \mathrm{Li}_{3}-\mathrm{CoA}, 0.63 \mathrm{mM} ; \mathrm{Na}_{2} \mathrm{ATP}, 4 \mathrm{mM}$ and phenylhydrazine/ $\mathrm{HCl}, \mathrm{pH} 6.0,3 \mathrm{mM}$. The reaction was started with Na-L-malate, $25 \mathrm{mM}$.

Malc enzyme (EC 1.1.1.40) activity was determincd following formation of NADPH from NADP ${ }^{+}$at $365 \mathrm{~nm}$ wavelength upon addition of malatc. The assay was modified after Stams et al. (1984), and the assay mixture contained: Tris/glycine, $\mathrm{pH} 7.4 ; 150 \mathrm{mM}$; $\mathrm{MgCl}_{2}, 12.5 \mathrm{mM} ; \mathrm{MnCl}_{2}, 12.5 \mathrm{mM} ; \mathrm{NAOP}^{+} 2 \mathrm{mM}$; the reaction was started with Na-L-malate, $15 \mathrm{mM}$. To avoid precipitation of $\mathrm{Mg}$ - or Mn-phosphates, the cell extract was prepared with triethanolamine buffer, $\mathrm{pH} 7.4,125 \mathrm{mM}$.

Pyruate synthase (EC 1.2.7.1) was measured following roduction of benzyl viologen with pyruvate $\left(c_{578}=8.65 \mathrm{mM}^{-1} \mathrm{~cm}^{-1}\right)$ according to Odom and Peck (1981).

Formate:ferredoxin oxidoreductase was assaycd following the reduction of benzyl viologen or methyl viologen $\left(a_{578}=9.7 \mathrm{mM}^{-1}\right.$ $\mathrm{cm}^{-1}$ ) with formate (Spormann and Thaner 1988).

Hydrogenase (EC 1.12.1.2) activity was analyzed following the reduction of benzyl viologen or methyl viologen with hydrogen (after Diekert and Thamer 1978).

$N A D^{1} / N A D P^{+}$ferredoxin oxidoreductase was monitored following the oxidation of benzyl viologen or methyl viologen at $578 \mathrm{~nm}$ wavelength with $\mathrm{N} \wedge \mathrm{D}^{+} / \mathrm{NADP}^{+}$. The assay mixture contained: potassium phosphate buffer, pH 7.5, $100 \mathrm{mM}$; benzyl or methyl viologen, $5 \mathrm{mM}$, and traces of $\mathrm{Na}_{2} \mathrm{~S}_{2} \mathrm{O}_{4}$. The reaction was started with $\mathrm{NAD}^{+} / \mathrm{NADP}^{+}, 0.5 \mathrm{mM}$.

The reverse reaction was assayed as reduction of benzyl or methyl viologen with $\mathrm{NADH} / \mathrm{NADPH}$. The reaction was started with $N A D H / N A D P H, 0.15 \mathrm{mM}$.

\section{Chemicals}

All chemicals were of analytical or reagent grade quality and were obtained from Merck. Darmstadt, Sigma, Deisenhofen, and Fluka, Ncu-UIm, FRG. Gases were obtained from Messer-Grieshcim, Darmstadt, FRG.

\section{Results}

\section{Enrichments and isolation}

Enrichment cultures with freshwater or saltwater medium containing $2 \mathrm{mM}$ glyoxylate as substrate were inoculated with $5 \mathrm{ml}$ sediment and sewage sludge from various sources. Gas production and turbidity formation started after 4 weeks in an enrichment culture with saltwater medium and anoxic sediment from Rio della Pergola. Subcultures inoculated with $5 \mathrm{ml}$ culture fluid tolerated glyoxylate concentrations up to $15 \mathrm{mM}$. After 4 to 5 transfers, mainly a thin, long rod was observed. 


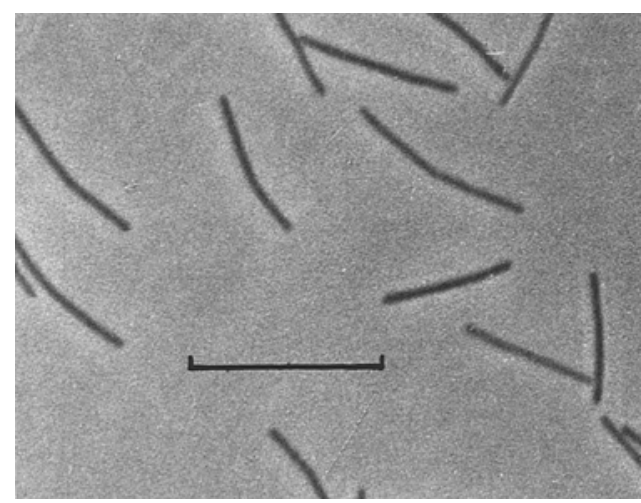

Fig. 1. Phase-contrast photomicrograph of strain PerGlx1. Bar equals $10 \mu \mathrm{m}$

A pure culture of this bacterium (strain PerGlx1) was obtained by two subsequent agar shake dilution serics with $5 \mathrm{mM}$ glyoxylate as substrate. Enrichment cultures with freshwater medium inoculated with sewage sludge from a municipal wastewater plant in Tübingen, FRG, started growing after 6 weeks, however, there was no clearly prevailing bacterium in this culture and growth was very slow.

\section{Morphological and cytological properties}

Cells of strain PerGlx1 were non-motile, long, thin rods, $0.5 \times 7-11 \mu \mathrm{m}$ in size (Fig. 1). Gram staining as well as the $\mathrm{KOH}$ test indicated a gram-negative cell wall architecture. Spore formation was never observed, nol even after 6 months of starvation. The guanosine-plus-cytosine content of the DNA was $44.1 \pm 0.2 \mathrm{~mol} \%$. No cytochromes could be detected by redox difference spectroscopy of crude cell extracts.

\section{Physiology, growth yield, and fermentation balance}

Strain PerGlx1 grew well in mineral medium containing $\mathrm{NaCl}$ from 30 to $370 \mathrm{mM}$ and $\mathrm{MgCl}_{2}$ from 1.9 to $15 \mathrm{mM}$; growth was possible up to $700 \mathrm{mM} \mathrm{NaCl}$ and $30 \mathrm{mM}$ $\mathrm{MgCl}_{2}$. Phosphate inhibited growth at concentrations $>20 \mathrm{mM}$. The temperature limits of growth were 12 and $35^{\circ} \mathrm{C}$. Optimal growth was observed at $32^{\circ} \mathrm{C}$. The $\mathrm{pH}$ range of growth was $6.7-8.3$, with an optimum of $\mathrm{pH}$ 7.7. Strain PerGlx1 grew at a maximum growth rate of $\mu=0.028 \mathrm{~h}^{-1}\left(\mathrm{t}_{\mathrm{d}}=25 \mathrm{~h}\right)$ (Fig. 2). Addition of traces of dithionite $(\leq 50 \mu \mathrm{M})$ helped subcultures to resume growth. Glyoxylate was the only substrate utilized; yeast extract was not required for growth and did not enhance the growth yield in combination with glyoxylate (Table 1). Neither inorganic electron acceptors (nitrate, sulfate, sulfite, thiosulfate, elemental sulfur) nor fumarate was reduced during glyoxylate oxidation. Glyoxylate was fermented completely to $\mathrm{CO}_{2}$, hydrogen, and glycolate (Table 2); $\mathrm{CO}_{2}$ was not determined. Cell matter formation was proportional to provided substrate up to $30 \mathrm{mM}$ glyoxylate (Table 2).

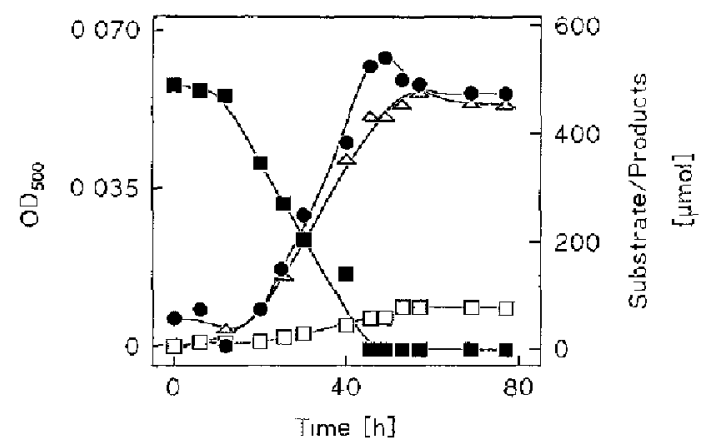

Fig. 2. Fermentation time course of strain PerGlx1 growing with $10 \mathrm{mM}$ glyoxylate. Experiments were performed at $28^{\circ} \mathrm{C}$ in $120 \mathrm{ml}$ serum bottles filled with $50 \mathrm{ml}$ medium under an $\mathrm{N}_{2} / \mathrm{CO}_{2}$ atmosphere, and samples were taken with syringes. $\mathrm{OD}_{500}$ : optical density at $500 \mathrm{~nm}$ wavclength ( ), glyoxylate (a), products: glycolate $(\square)$, and hydrogen $(\triangle)$

Table 1. Substrates tested for growth with strain PerGix1; concentration of substrates added was $10 \mathrm{mM}$, unless indicated otherwise (in parentheses)

Compound utilized:

glyoxylate

Compounds not utilized:

formate, acclate, propionate, glycolate, DL-lactate, DL-glycerate, thioglycolate

oxalate, malonate, DL-malate, succinate, fumarate, tartrate methanol, ethanol, glycerol, ethylene glycol

glucose (5), fructose (5), arabinose (5), xylose (5)

formaldehyde $(1 ; 2)$, glycolaldehyde $(2 ; 5)$, glyceraldehyde $(2 ; 5)$ pyruvate (5)

glycine (5), alanine (5)

yeast extract $(0.1 \%)$

Compounds not utilized in combination with $10 \mathrm{mM}$ glyoxylate: acetate $(5 ; 10)$, glycine $(5 ; 10)$, pyruvate $(5)$, succinate $(5)$, Dr-malate (5), fumarate (10), yeast extract $(0.1 \%)$

In coculture experiments with Methanospirillum hungatei as hydrogen consuming partner, no shift of the fermentation balance towards less glycolate production could be observed (data not shown). Such cocultures were not able to grow either with glycolate as substrate.

\section{Enzymes involved in glyoxylate degradation}

Enzymes were assayed in cell-free extracts of strain PerGlx1. The enzymes detected (Table 3) were present at activities sufficient to account for the dissimilatory turnover of glyoxylate $\left(0.52 \mu \mathrm{mol} \cdot \mathrm{min}^{-1} \cdot \mathrm{mg}^{-1}\right.$ protein). Glyoxylate reductase was specific for NADH; NADPH was not oxidized, and bydroxypyruvate was not reduced. Glycolate oxidation was not observed, neither with $\mathrm{NAD}^{+}$nor with APAD (acetyl pyrimidine adenine dinucleotide, $E^{\circ \prime}=-248 \mathrm{mV}$; Bergmeyer 1974) as electron acceptor, nor with dinitrophenylhydrazine as glyoxylate trap. Instcad, a malyl-CoA lyasc/malate:CoA ligasc enzyme system was detccted at significant activity. The forward reaction was ADP-dependent, the backward 
Table 2. Stoichiometry of fermentation and growth yields of strain PerGlx1

\begin{tabular}{|c|c|c|c|c|c|c|c|c|}
\hline \multirow{2}{*}{$\begin{array}{l}\text { Glyoxylate } \\
\text { concentration } \\
\text { (mM) }\end{array}$} & \multirow{2}{*}{$\begin{array}{l}\text { Glyoxylare } \\
\text { degraded } \\
\text { ( } \mu \text { mol) }\end{array}$} & \multirow{2}{*}{$\begin{array}{l}\text { Optical } \\
\text { density } \\
\text { reached } \\
\mathrm{E}_{500}\end{array}$} & \multirow{2}{*}{$\begin{array}{l}\text { Cell alry } \\
\text { mass } \\
\text { formed } \\
\text { (mg) }\end{array}$} & \multirow{2}{*}{$\begin{array}{l}\text { Substrale } \\
\text { assimilated }^{b} \\
\text { (umol) }\end{array}$} & \multicolumn{2}{|c|}{$\begin{array}{l}\text { Products formed } \\
(1 \mathrm{~mol})\end{array}$} & \multirow{2}{*}{$\begin{array}{l}\text { Electron } \\
\text { recovery } \\
(\%)\end{array}$} & \multirow{2}{*}{$\begin{array}{l}\text { Molar growth } \\
\text { yield } \\
(\mathrm{g} / \mathrm{mol})\end{array}$} \\
\hline & & & & & glycolate & $\mathrm{H}_{2}$ & & \\
\hline 5 & 231 & 0.026 & 0.31 & 11 & 54 & 235 & 92 & 1.3 \\
\hline 10 & 512 & 0.069 & 0.92 & 41 & 140 & 547 & 103 & 1.8 \\
\hline 15 & 751 & 0.105 & 1.34 & 60 & 156 & 774 & 90 & 1.8 \\
\hline
\end{tabular}

Growth experiments were carried out in $120 \mathrm{ml}$ serum flasks filled with $50 \mathrm{ml}$ mineral medium under a $\mathrm{N}_{2} / \mathrm{CO}_{2}(90 \% / 10 \%)$ atmosphere a Cell dry matter values were calculated via cell density using an experimentally determined conversion factor $\left(0.10 D_{500}=25\right.$ mg dry matter/1)

${ }^{b}$ Glyoxylate assimilated was calculated according to the formula: $17 \mathrm{C}_{2} \mathrm{H}_{2} \mathrm{O}_{3} \rightarrow 4\left\langle\mathrm{C}_{4} \mathrm{H}_{7} \mathrm{O}_{3}\right\rangle+3 \mathrm{H}_{2} \mathrm{O}+18 \mathrm{CO}_{2}$

Table 3. Enzymes involved in glyoxylate degradation by strain PerGlx1

\begin{tabular}{|c|c|c|}
\hline Enzyme & EC number & $\begin{array}{l}\text { Specific } \\
\text { activity } \\
\left(\mu \mathrm{mol} \cdot \mathrm{min}^{-1}\right. \\
\mathrm{mg} \\
\left.\text { protcin }^{-1}\right)\end{array}$ \\
\hline $\begin{array}{l}1 \text { Glyoxylate reductase (NAD) } \\
2 \text { Malyl-CoA lyase plus }\end{array}$ & 1.1 .1 .26 & $0.9-1.9$ \\
\hline 3 Malate:CoA ligase & - & 0.25 \\
\hline 4 Malic enzyme (NADP ${ }^{+}$) & 1.1 .1 .40 & 0.7 \\
\hline 5 Pyruvate synthase & 1.2 .7 .1 & $2.2(\mathrm{BV})$ \\
\hline 6 IIydrogenase & 1.12 .1 .2 & $\begin{array}{l}1.7(\mathrm{BV}) \\
0.7(\mathrm{MV})\end{array}$ \\
\hline $\begin{array}{l}7 \mathrm{NAD}^{+} \text {:ferredoxin } \\
\text { oxidoreductase }\end{array}$ & - & $\begin{array}{l}0.17(\mathrm{BV}) \\
1.1(\mathrm{MV})\end{array}$ \\
\hline $\begin{array}{l}7 \text { NADH:ferredoxin } \\
\text { oxidoreductase } \\
8 \text { NADP }{ }^{+} \text {:Curredoxin }\end{array}$ & 一 & $0.7(\mathrm{BV})$ \\
\hline $\begin{array}{l}\text { oxidoreductase } \\
8 \text { NADPH :ferredoxin }\end{array}$ & - & n.d. \\
\hline $\begin{array}{l}\text { oxidareductase } \\
9 \text { Formate:ferredoxin }\end{array}$ & - & $1.36(\mathrm{BV})$ \\
\hline oxidoreductase & - & $\begin{array}{l}0.13 \text { (BV) } \\
0.16 \text { (MV) }\end{array}$ \\
\hline
\end{tabular}

Benzyl viologen (BV) or methyl viologen (MV) were used as electron donor or acceptors; n.d. = not determined

reaction, forming acelyl-CoA and glyoxylate from L-malate, was CoASH and ATP-cependent. Malic enzyme activity was $\mathrm{NADP}^{+}$-dependent, but oxaloacetate was not decarboxylated to pyruvate as described for malic en7yme, ГC 1.1.1.40.

The following enzymes were checked for, but could not be detected by the methods indicated: malate synthase, EC 4.1.3.2 (Dixon and Kornberg 1959), malate $\mathrm{NAD}^{+} / \mathrm{NADP}^{+}$oxidoreductase, EC 1.1.1.37/1.1.1.38 (Stams et al. 1984), phosphotransacetylase, EC 2.3.1.8 (Bergmeyer 1974), isocitrate lyase, EC 4.1.3.1 (Dixon and Konnberg 1959), carbonmonoxide dehydrogenase, EC 1.2.99.2 (Diekert and Thauer 1978), D-glycerate NAD ${ }^{+}$/ NADP ${ }^{+}$oxidoreductase, EC 1.1.1.81 (Kohn and Jakoby 1968), formate $\mathrm{NAD}^{+}$oxidoreductase, EC 1.2.1.2 (Spormann and Thauer 1988), pyruvate $\mathrm{NAD}^{-}$oxidoreductase
(Bergmeyer 1974), and oxaloacetate decarboxylase, EC 4.1.1.3 (Dimroth 1981).

\section{Discussion \\ Physiology and taxonomic status of strain PerGlx1}

In the present study, lermentative degradation of glyoxylate is described for the first time. The newly isolated strain PerGlx1 ferments glyoxylate to carbon dioxide, hydrogen, and glycolate, approximately according to the following equation:

4 glyoxylate $^{-}+3 \mathrm{H}^{+}+3 \mathrm{H}_{2} \mathrm{O} \rightarrow$

$6 \mathrm{CO}_{2}+5 \mathrm{H}_{2}+$ glycolate $^{-}$

Glyoxylate was found to be the only substrate metabolized by this new strictly anaerobic, gram-negative isolate. Gram type, morphology, lack of spore formation, and the guanine-plus-cytosine content of the DNA $(44.1 \pm 0.2 \mathrm{~mol} \%)$ of strain PerGlx 1 give first indications to affiliate this highly specialized isolate with the family Bacteroidaceae. Further studies are required to define a new species for this bacterium.

Our isolate was sensitive to phosphate at concentrations higher than $20 \mathrm{mM}$; enrichment and isolation was therefore possible only in a low-phosphate medium as used here.

Enrichment cultures with anacrobic sewage sludge did not select for a single prevailing bacterium indicating that glyoxylate degradation in these enrichments depended on a complex interaction of various bacteria.

\section{Biochemistry}

The pathway of glyoxylate degradation was studied by assays for key enzymes of known glyoxylate degradation pathways. Neither enzymes of the glycerate pathway such as glycerate: $\mathrm{NAD}\left(\mathrm{P}^{+}{ }^{+}\right.$oxidoreductase, EC 1.1.1.60 (Hansen and Hayashi 1962) nor of the $\beta$-hydroxyaspartate pathway or the dicarboxylic acid pathway via malate (e.g. malate synthase, malate $\mathrm{NAD}^{+} / \mathrm{NADP}^{+}$ oxidoreductasc, or oxaloacetate decarboxylase; Kornberg and Morris 1965; Kornberg and Sadler 1960) were 


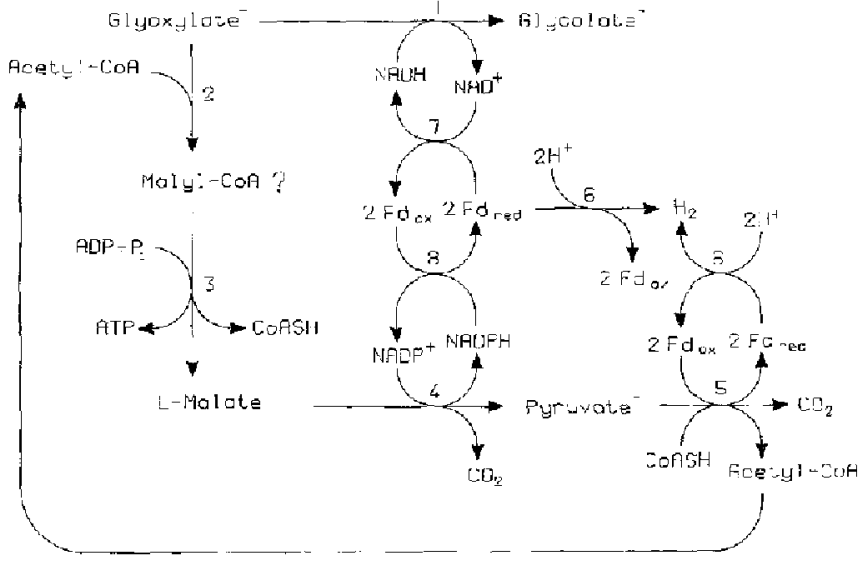

Fig. 3. Hypothetical pathway of glyoxylafe degratation by strain PerGlx1 as suggested by our results. Numbers refer to the following enzyme activities detected in cell-free extracts: (1) glyoxylate reductasc, (2) maly]-CaA byase, (3) malate:CoA ligase, (4) malic enzyme, (5) pyruwale synthase, (6) hydrogenase, (7) NAD ${ }^{+}$/NADII: ferredoxin oxidoreductasc, (8) NADPH:ferredoxin oxidoreductase. Abbreviations: $\Gamma \mathrm{d}_{\mathrm{ox} ; \mathrm{red}}$, oxidized/reduced ferredoxin

detected. We also checked for a glyoxylate oxidizing enzyme activity, for formate formation from glyoxylate, and for a methylene tetrahydrofolate oxidizing enzyme, however, without success.

Instead, enzymes of a new pathway were detected. The reaction sequence (Fig. 3) starts with the condensation of glyoxylate and acetyl-CoA, probably to form malyl-CoA by malyl-CoA lyase; malyl-CoA is apparently converted to malate by malate: $C O A$ ligase. The free energy of this assumed thioester bond is used to phosphorylate ADP through substrate level phosphorylation. Establishment of this pathway was based on a coupled enzyme assay in both reaction directions: the formation of malate from acetyl-CoA and glyoxylate was ADP-dependent. Oxidative decarboxylation of malate by an $\mathrm{NADP}^{\prime}$-dependent malic enzyme yields pyruvate which is decarboxylated oxidatively by pyruvate synthase.

Finally acetyl-CoA, the acceptor for glyoxylate in this pathway, is regenerated to complete the cycle. This new degradation pathway resembles the malate pathway characteristic of certain Pseudomonas sp. growing aerobically with glycolate (Komberg and Sadler 1960), however, an activated form of malate, probably malylCoA, is the key intermediate of this new pathway. It conserves the free energy of the acetyl-CoA thioester linkage in the condensation reaction $\left(\Delta G^{\circ \prime}=-7.1 \mathrm{~kJ} /\right.$ mol), and synthesizes 1 ATP by substrate level phosphorylation. So far, malyl-CoA lyase and malate:CoA ligase are known only as part of the serine-isocitrate-lyase pathway used by certain aerobic methylotrophic bacteria (Gottschalk 1986). Rhodopseudomonas sphaeroides growing anaerobically in the light with malate or glutamate uses the same enzymes (Tuboi and Kikuchi 1965). However, unlike these pathways, metabolism in strain PerGlx1 proceeds in the opposite direction: acetyl-CoA serves as glyoxylate acceptor, and malyl-CoA appears to be formed.

\section{Energetics}

Through the reaction sequence above, the major part (about $75 \%$ ) of glyoxylate is oxidized to $\mathrm{CO}_{2}$, and two pairs of electrons are released per glyoxylate molecule. Malic enzyme $\left(\mathrm{E}^{\circ \prime}=-331 \mathrm{mV}\right)$ transfers electrons to NADPH $\left(\mathbf{E}^{\circ}=-324 \mathrm{mV}\right)$, and pyruvate oxidation to acetyl-CoA $+\mathrm{CO}_{2}\left(\mathrm{E}^{\circ}=-470 \mathrm{mV}\right)$ reduces a low-potential electron carrier, probably ferredoxin.

A hydrogenase enzyme reacts with viologens and reoxidizes reduced ferredoxin to $\mathrm{H}_{2}\left(\mathrm{E}^{\circ}=-414 \mathrm{mV}\right)$. Ferredoxin appears to play a role also as an electron carrier between NADPH generated in the malic enzyme reaction $\left(\mathrm{NADP}^{+}\right.$:ferredoxin oxidoreductase) and NADI which is reoxidized in glyoxylate reductase reaction to glycolate (see Fig. 3). Direct transhydrogenation from NADPH to $\mathrm{NAD}^{+}$or vice versa was not detected.

The experimentally determined stoichiometry of glyoxylate conversion (Eq. (1)) indicates that a comparably small fraction of the total electron pool is used to reducc glyoxylate to glycolate $\left(\mathrm{E}^{\circ}=-92 \mathrm{mV}\right.$; Thauer 1988). If we assume that the low-potential electrons from pyruvate oxidation are released entirely as $\mathrm{H}_{2}$, the NADPH electrons from malate oxidation obviously go two ways: two thirds are released as $\mathrm{H}_{2}$ while one third flows into glyoxylate reduction. A similar dismutation is known for the $\mathrm{NADH}$ electrons obtained in the glyceraldehyde phosphate dehydrogenase reaction: Pure cultures of Clostridium pasteurianum channel part of these electrons into butyrate formation from acetyl-CoA, and another part is released as $\mathrm{H}_{2}$ (Thauer et al. 1977).

Glyoxylate fermentation according to Eq. (1) releases $35.7 \mathrm{~kJ}$ per mol glyoxylate (Thauer et al. 1977). Three mol ATP are synthesized by substrate level phosphorylation per $4 \mathrm{~mol}$ glyoxylate metabolized; only $47.6 \mathrm{~kJ}$ is available per mol ATP, therefore. This is hardly enough for irreversible ATP synthesis in a growing cell; usually at least $70 \mathrm{~kJ}$ is calculated per mol ATP synthesized (Thauer et al. 1977), and the molar growth yield observed fits into this frame. Thus it has to be assumed that part of the ATP synthesized by substrate level phosphorylation is invested either in substrate uptakc or in hydrogen release against the electrochemical potential. Similar ATP-requiring shifts of thermodynamic reaction equilibria have been postulated especially for syntrophic oxidations of alcohols and fatty acids (Schink 1991). Reduction of part of glyoxylate to glycolate helps to improve the energy balance of glyoxylate fermentation; complete oxidation to $\mathrm{CO}_{2}$ and $\mathrm{H}_{2}$ only releases even less energy, and only $26.4 \mathrm{~kJ}$ would be available per ATP synthesized:

glyoxylate ${ }^{-}+\mathrm{H}^{+}+\mathrm{H}_{2} \mathrm{O} \rightarrow 2 \mathrm{CO}_{2}+2 \mathrm{H}_{2}$

$\Delta \mathrm{G}^{\mathrm{or}}=-26.4 \mathrm{~kJ}$ per mol glyoxylate.

The ratio of glyoxylate oxidized over glyoxylate reduced is very stable with our isolate, and could not be influenced significantly in cocultures with hydrogen-scavening partner bacteria. Reduction of glyoxylate to glycolate with NADH electrons is a nearly irreversible reaction ( $A \mathrm{E}^{\circ}=$ $-228 \mathrm{mV}$ ), and it was impossible to measure a reverse reaction in cell-free extracts of strain PerGlx1, not even in the presence of dinitrophenylhydrazine as aldehyde 
trap. The high gain of overall reaction entropy by glycolate formation has to be strictly controlled by the bacterium to maintain optimal efficiency of $\Lambda T P$ synthesis. Oxidation of glycolate via glyoxylate to $\mathrm{CO}_{2}$ is not possible with strain PerGlx1, neither in pure nor in mixed culture with methanogenic bacteria. This oxidation requires a special energy-dependent electron shifl in the first step which appears to operate in syntrophic glycolateoxidizing cultures isolated recently in our laboratory (Friedrich et al. 1991).

Strain PerGlx1 has been deposited with Deutsche Sammlung von Mikroorganismen, Braunschweig, FRG.

Acknowledgement. Wo thank the Fonds der Chemischen Industrie, Frankfurt/Main, for financial support.

\section{References}

Bartholomew JW (1962) Variables influencing results, and precise definition of steps in gram staining as a mcans of standardizing the results obtained. Stain Technol 37:139-155

Bergmeyer HU (1974) Methoden der enzymatischen Analyse, vol 1; 2. Verlag Chemie, Wenheim/Bergstr, FRG

Bradford MM (1976) A rapid and sensitive method for the quantitation of microgram quantities of protein ulilizing the principle of protein-dye binding. Anal Biochem $72: 248-254$

Brunner H, Chuard E (1886) Mitheilungen. Phytochemische Studien. Disch Chem Ges 19:595

Cord-Ruwisch R (1985) A quick method for the determination of dissolved and precipitated sulfides in cultures of sulfate-reducing bacteria. J Microbiol Methods 4:33-36

DeLey $J(1970)$ Reexamination of the association between melting point, buoyant density, and the chemical base composition of deoxyribonucleic acid. J Bacteriol 101:738-754

Diekert GB, Thauer RK (1978) Carbon monoxide oxidation by Clostridium thermoaceticum and Clostridium formiconceticum. I Bacteriol 136:597-606

Dimroth P (1981) Characterization of a membrane-bound biotincontaining enzyme: oxaloacetate decarboxylase from Klebsiella aerogenes. Eur J Biochem 115:353-358

Dixon GH. Kornberg HL (1959) Assay methods for key enzymes of the glyoxylate cycle. Biochem J $72: 3 p$

Dörner C, Schink B (1990) Clostridium homopropionicum sp. nov., a new strict anaerobe growing witl 2-, 3-, or 4-hydroxybutyrate. Arch Microbiol 154:342-348

Friedrich M, Laderer U, Schink B (1991) Fermentative degradation of glycolic acid by defined syntrophic cocultures. Arch Microbiol 156:398-404

Gottschalk G (1986) Bacterial metabolism, 2nd edn. Springer, New York Berlin Heidelberg

Gregersen $T$ (1978) Rapid method for distinction of Gram-negative from Gram-positive bacteria. Eur J Appl Microbiol Biotechnol 5:123-127

Hansen RW, Hayashi JA (1962) Glycolate metabolism in Escherichia coli. J Bacteriol 83:679-687

International Union of Biochemistry (1984) Enzyme nomenclature 1984. Academic Press, Orlando, Florida

Kohn LD, Jakoby WB (1968) Tartaric acid metabolism VIJ. Crystalline hydroxypyruvate reductase (D-glycerate dehydrogenasc). J Biol Chem 243:2494-2499

Kornberg HL, Morris JG (1965) The utilization of glycollate by Micrococcus denitrificans: the beta-hydroxy-aspartate pathway. Biochem J 95:577-586

Kornberg HL, Sadler JR (1960) Microbial oxidation of glycollate via a dicarboxylic acid cycle. Nature $185: 153-155$
Lippmann EO von (1894) Über organische Säuren aus Rübensaft. Dtsch Chem Ges 24:3303-3305

Marmur J (1961) A procedure for the isolation of deoxyribonucleic acid from microorganisms. J Mol Biol 3:208-218

Mathies C, Mayer F, Schink B (1989) Fermentative degradation of putrescine by new strictly anaerobic bacteria. Arch Microbiol $151: 498-505$

Odom JM, Peck HD (1981) Localisation of dehydrogenases, reductases and electron transfer components in the sulfate-reducing bacterium Desulfovibrio gigas. J Bactcriol 147:161 - 169

Pfennig $\mathrm{N}$ (1978) Rhodocychs purpureus gen. nov sp. nov, a ringshaped, vitamin $B_{12}$-requiring member of the family Rhodospirillaceac. Int J Syst Bacteriol 28:283-288

Procházková L (1959) Bestimmung der Nìtrate im Wasser. Z Anal Chem 167:254-260

Schink B (1984) Firmentation of 2,3-butanediol by Pelohacter carbinolicus sp. nov. and Pelobacter propionicus sp. nov., and evidence for propionate formation from $\mathrm{C}_{2}$ compounds. Arch Microbiol 137:33-41

Schink B (1991) Syntrophism among prokaryotes. In: The prokaryotes. Balows $\Lambda$, Trüper $H G$, Dworkin $M$, Harder $W$, Schlcifer KH (eds) Springer, New York Berlin Heidelberg (in press)

Schink B, Pfennig N (1982) Fermentation of trihydroxybenzenes by Pleobacter acidigallici gen. nov. spec. now, a new strictly anaerobic, non-sporeforming bacterium. Arch Microbiol 133; $195-201$

Spormann AM, Thauer RK (1988) Anaerobic acetate oxidation to $\mathrm{CO}_{2}$ by Desulfotomaculum acetoxidans. Demonstration of enzymes required for the operation of an oxidative acetyl-CoN carbon monoxide dehydrogenase pathway. Arch Microbiol $150: 374-380$

Stams AJM, Kremer DR, Nicolay K, Weenk GH, Hensen TA (1984) pathway of propionate formation in Desulfobulbus propionicus. Arch Microbiol 139:167-173

Stewart R, Codd GA (1981) Glycollate and glyoxylate excretion by Sphaerocystis schroeteri (Chlorophyceae). Br Phycol J 16:177 182

Thater RK (1988) Citric-acid Cycle, 50 years on. Eur J Biochem $176: 497-508$

Thauer RK, Jungermann K, Decker K (1977) Encrgy conservation of chemotrophic anacrobic bacteria. Bacteriol Rev $41: 100-$ 180

Tuboi S, Kikuchi G (1965) Enzymic cleavage of malyl-cocnzyme A into acetyl-coenzyme $A$ and glyoxylie acid. Biochim Biophys Acta 96:148-153

Widdel F, Kohring GW, Mayer F (1983) Studies on dissimilatory sulfate-reducing bacteria that decompose fatty acids. III. Characterization of the filamentous gliding Desulfonema limicola gen. now. sp. nov, and Desulfonema magnum sp. nov. Arch Microbiol 134:286-294

Widdel F, Pfennig N (1981) Studies on dissimilatory sulfate-reducing bactcria that decompose fatty acids. I. Isolation of new sulfate reducing bacteria enriched with acetate from saline environments. Description of Desulfobacter postgatei gen. nov. sp. nov. Arch Microbiol 129:395-400

Widdcl F, Pfennig N (1984) Dissimilatory sulfate- or sulfur reducing-bacteria. In: Krieg NR, Holt JG (eds) Bergey's manual of systematic bacteriology, IXth edn, vol 1. Williams \& Wilkins, Baltimore London

Yamada FW, Jakoby WB (1958) Enzymatic utilization of acetylenic compounds. I. An enzyme converting acetylendicarboxylic acid to pyruvate. J Biol Chem 233:706-711

Zeltich I (1953) Oxidation and reduction of glycolic and glyoxylic acids in plants. J Biol Chem $201: 719-726$ 